\title{
Taste Sensitivity to Phenylthiocarbamide Found in South Sinai Bedouin Tribes
}

\author{
Anna M. Chumakova ${ }^{1}$, Leonid Kalichman², Eugene D. Kobyliansky ${ }^{3}$ \\ ${ }^{1}$ Research Institute and Museum of Anthropology, Moscow State University, Moscow, Russia \\ ${ }^{2}$ Department of Physical Therapy, Recanati School for Community Health Professions, Faculty of Health Sciences at Ben-Gurion \\ University of the Negev, Beer-Sheva, Israel \\ ${ }^{3}$ Department of Anatomy and Anthropology, Sackler Faculty of Medicine, Tel Aviv University, Tel Aviv, Israel
}

\begin{abstract}
A B S T R A C T
The aim of this work was to study taste sensitivity to phenylthiocarbamide (PTC) amongst Bedouin tribes and compare the Bedouins with Arab and Jewish populations. Data obtained by the classic method of serial dilutions in 317 healthy male Bedouins, aged 16-70 belonging to different tribes, were examined. We discovered significant differences in chemosensitivity to PTC in the Bedouin communities. A high frequency of the tallele was documented in the Bedouin tribes of Hamada, Muzeina, and "other Bedouins" and a relatively low level of the $t$ allele frequency in the Gebelia tribe. The frequencies of non-tasters amongst Arab groups were similar in values to those of the Gebelia tribe. Three other Bedouin tribes showed very high values for the non-tasters' frequencies. The revealed intertribal differences can be explained by the genetic drift in isolated populations, on the other hand, this may be the result of endogamy.
\end{abstract}

Key words: sensitivity to phenylthiocarbamide (PTC), dilution method, threshold distribution, gene frequency, Bedouins of South Sinai

\section{Introduction}

Approximately 90 years have passed since the discovery of a trait that separates the human populations' ability to discern the bitter taste of phenylthiocarbamide (PTC) in a certain concentration and depending on the ability of the taste buds to respond to the chemical functional group $=\mathrm{N}-\mathrm{C}=\mathrm{S}$. That thiocyanate moiety was also present in a chemical related to PTC, named 6-n-propylthiouracil (PROP). In later works, PROP was used to study taste sensitivity instead of PTC, as a less toxic substance (slightly safer when swallowing). Significant progress has been noted by numerous molecular biological and anthropogenetic studies. In most populations, sensitivity to PTC is determined by two alleles T and $t$, although, in the 1970s, a study ${ }^{1}$ identified individuals whose sensitivity allowed them to be called "supertasters", denoting human hypersensitivity to PTC, determined by the presence of a special T2 allele, codominant to the T allele. It is currently known that the ability to sense the bitter taste of the organic compound PTC and PROP, is encoded by the autosomal gene TAS2R38, located at the 35q locus of chromosome 7 . The products of the gene expression of the allelic variants in the receptor cells of the tongue (at the bottom of the taste pores) are G-proteins, differing in tasters and non-tasters by three amino acids located at positions 49, 262, and 296 in the finished protein. According to modern data, this gene is also expressed in nasal epithelial cells, in the ciliated epithelium of the bronchi, and the gastrointestinal tract ${ }^{2}$.

A bimodal distribution is typical for the thresholds ${ }^{3}$ of taste sensitivity to PTC in most human populations, with one peak of the curve indicating the tasters (who can detect the bitter taste of PTC/PROP), and another peak indicating the non-tasters (who cannot detect the bitterness).

Later, this pattern of phenotypic manifestation was clarified and supplemented with new information obtained, in particular, in the study of African populations. In 2012, Campbell et al ${ }^{4}$ reported new rare polymorphisms at the TAS2R38 locus that recently emerged in Africa. High frequencies of haplotypes in Africa, associated with intermediate sensitivity to bitter taste, were revealed. Some of the rare substitutions in various groups of Africans led to the expansion of polymorphism in the discussed locus, and some to the formation of pseudogenes ${ }^{5}$. Accordingly, in such cases, the distribution becomes more complex rather than bimodal. 
In the analytical work of Risso et $\mathrm{al}^{6}$, on a wide range of human samples, it was shown that the currently observed patterns of variability to PTC/PROP sensitivity are mainly caused by demographic reasons, rather than by the action of selection.

Numerous informative and diverse data have been collected as to the association of human sensitivity to PTC and human mental and somatic diseases ${ }^{7}$, age ${ }^{8}$, morphological status ${ }^{9}$, smoking ${ }^{9}$, propensity to alcoholism ${ }^{10}$, etc. An interesting anthropological review was recently published summarizing the results of studies (often conflicting) on the associations of bitterness perception with anthropometric characteristics, age, gender, ethnicity, obesity ${ }^{11}$. Another study reported on the association of gustatory sensitivity with physical characteristics in Chuvash girls ${ }^{12}$. A large amount of data has been reported on the sensitivity to PTC observed in various ethnoterritorial groups. Thus, in a molecular genetic study on the variability of the sensation of bitterness, which was carried out by Wooding et al. ${ }^{13}$ for the coding region of the PTC gene, chromosomes from African, Asian, European, and North American populations were studied. As a result, two haplotypes of intermediate frequency were found, corresponding to the phenotypes "taster" and "non-taster", which had similar frequencies in Africa, Asia, and Europe. According to $\mathrm{Kim}^{14}$, the gene that determines the ability of receptors to sense bitterness exists in seven different allelic variants, and only two of them, "tasters" and "non-taster", are distributed with a high frequency outside Africa. Some of the remaining five haplotypes are likely to have intermediate PTC sensitivity. It was found ${ }^{13}$ that in humans, ancient balancing natural selection (aimed at preventing poisoning with plant toxins) acted to maintain the "taster" and "nontaster" alleles. However, the currently observed variation at this locus can be explained by demographic causes ${ }^{15}$, not by selection.

In 2014, Fisher et al ${ }^{16}$ reported on the effect of TAS2R38 haplotypes on the relationship between perceived bitterness of PROP and basic tastes (salty, sweet, sour, and bitter). Robino et $\mathrm{a}^{17}$ in 2014 studied the association between PROP phenotypes and TAS2R38 polymorphisms in six populations of the Caucasus and Central Asia (along the Silk Road). They found a very high frequency of supertesters in Tajikistan (31.3\%) and Armenia (39.0\%) and a higher frequency of non-tasters in Georgia (50.9\%). Guo and Reed ${ }^{18}$ published extensive worldwide data on the frequencies of phenotypes of non-tasters, (some data were used as comparative material in our study).

Our goal was to analyze the prevalence of taste sensitivity to PTC and determine the prevalence of non-tasters in the Bedouin tribes of South Sinai, Egypt. This is a unique complex human population with pronounced endogamy. We assume that the tradition of closely related marriages affects the distribution of genetic traits, and leads to interpopulation discrepancies in the frequencies of phenotypes and related genotypes. Therefore, another goal was to compare the frequencies of the phenotypes of tasters and non-tasters, as well as the frequencies of the corresponding alleles. We also studied the differences in the frequencies of the $t$ alleles that control insensitivity to the bitterness of PTC between Bedouin, Arab and Jewish populations.

\section{Materials and Methods}

Taste sensitivity to the bitterness of PTC of four Bedouin samples was studied. Two samples comprised the Bedouins of the large Gebelia and Muzeina tribes. Data on the Hamada and Aleigat tribes, following the results, obtained earlier ${ }^{19}$ were combined into a Hamada tribe sample. The cumulative group "other Bedouin tribes" included representatives of small tribes such as the Gararsha, Beni-Vassal, Avlad Said, Haveitat, and Savalcha. In total, field data on taste sensitivity to PTC was collected in 317 healthy male Bedouins 16-70 years old (Table 1).

Taste sensitivity to the bitterness of PTC was determined by the classical method of successive standard dilutions of the PTC solution ( $1.3 \mathrm{~g} / \mathrm{l}$ of boiled drinking water $)^{20}$, applying the solutions to the tongue root of the subjects, commencing with the most diluted (No. 15, PTC concentration $0.0001 \mathrm{~g} / \mathrm{l})$. In the absence of sensation, more and more concentrated solutions were employed in increasing order, until bitterness was detected. The solution in which the examined person reported a bitter taste was considered the threshold solution; the number of individuals who felt bitterness with testing solutions numbered 1 to 15 according to the PTC concentration, was recorded.

Individuals with a threshold sensitivity from 1 to 3 dilutions (PTC concentration $1.3-0.33 \mathrm{~g} / \mathrm{l}$ ), were categorized as non-tasters. More sensitive individuals who felt a bitter taste of PTC dilutions with a concentration of 0.1625-0.0001 g/l, were categorized as tasters. The same methodology was used to collect materials from Jewish samples (a total of 468 people from Eastern and Central Europe, the Middle East, and North Africa), previously described by Kobyliansky et al. ${ }^{21}$ These data also served as comparative material in our work.

The calculation of allele frequencies of the gene coding the chemosensitivity to PTC was performed according to the Hardy-Weinberg law, although the authors were aware that in small populations, with a tendency for endogamy, deviations from the ideal Hardy-Weinberg model are significant. Statistical analysis (descriptive statistics and comparisons using the Pearson $\chi^{2}$ method) was performed using the Statistica 10 and Microsoft Office Excel software.

\section{Results}

Figures 1-4 illustrate the distributions of cutoff concentrations of PTC in four Bedouin male samples. A simple visual assessment of the distributions suggests that the Gebelia tribe significantly differs from other Bedouin tribes. The phenotypic prevalence of tasters (81.38\%) in this tribe was statistically significantly higher compared to the non-tasters (19.72\%). The prevalence of non-tasters in the remaining Bedouin samples varied from $48.45 \%$ to $56.82 \%$, approximately half of the corresponding samples 


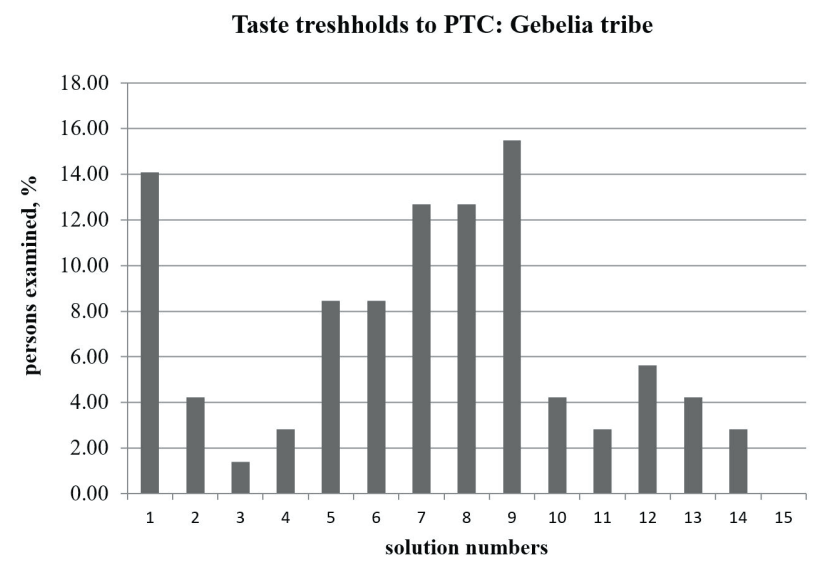

Fig. 1. Taste thresholds for PTC in the Gebelia tribe.

Taste treshholds to PTC: Hamada tribe

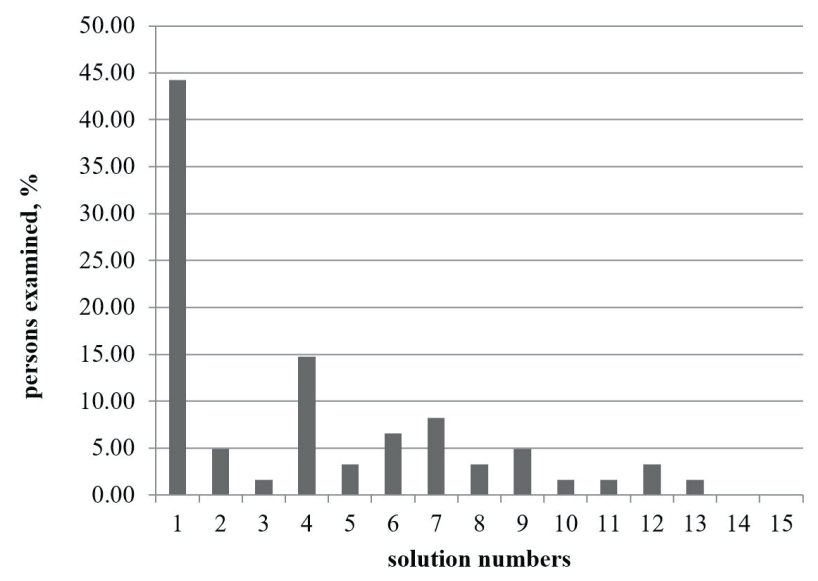

Fig. 2. Taste thresholds for PTC in the Hamada tribe.

(Table 1). The peak value of the distribution for non-tasters in all four samples was similar, however, the mode of the distributions of tasters was different, i.e., the largest number of tasters in the Gebelia tribe was detected by solution No. 9 (PTC concentration = $0.0051 \mathrm{~g} / \mathrm{l})$. In "other Bedouin tribes", tasters were detected by solution No.8 (0.0102 g/l), in the Muzeina tribe solution No. 6 (0.0406 $\mathrm{g} / \mathrm{l})$, and in the Hamada tribe, solution No.4 (0.1625 g/l). Myachina et al. ${ }^{22}$ discovered similar data in native Arab populations of Iraq and Syria. Detection of a bitter taste of PTC was found in solution concentrations of 0.02-0.08 $\mathrm{g} / \mathrm{l}$, very similar to data from the Muzeina tribe. The maximum threshold values of tasters in the Jewish samples ${ }^{21}$ were more often solution concentrations of 0.0051-0.0102 $\mathrm{g} / \mathrm{l}$, which are more analogous to the characteristics of the taste sensitivity of the Gebelia tribe and "other Bedouin tribes". By comparing the distribution of threshold values of PTC sensitivity in four Bedouin tribes using the Pearson $\chi^{2}$ method, statistically significant differences were found between the Gebelia and all other tribes. Differences between the Muzeina and "other Bedouin tribes" were also significant (Table 2).

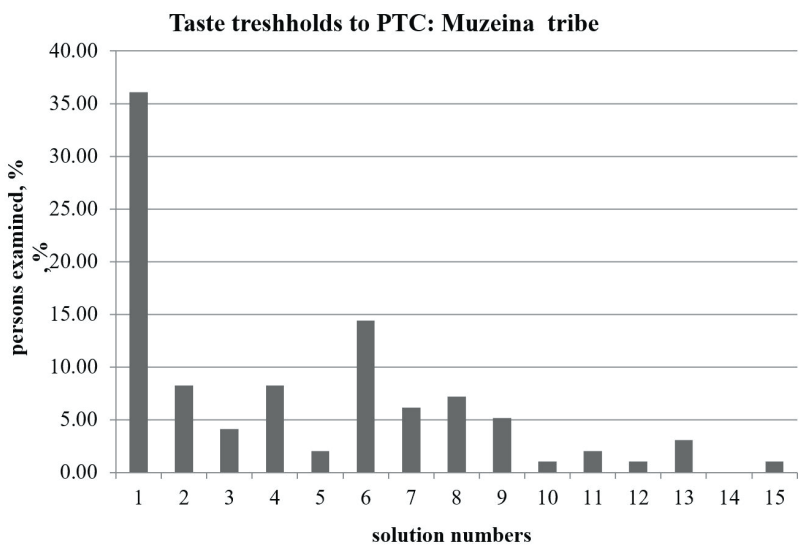

Fig. 3. Taste thresholds for PTC in the Muzeina tribe.

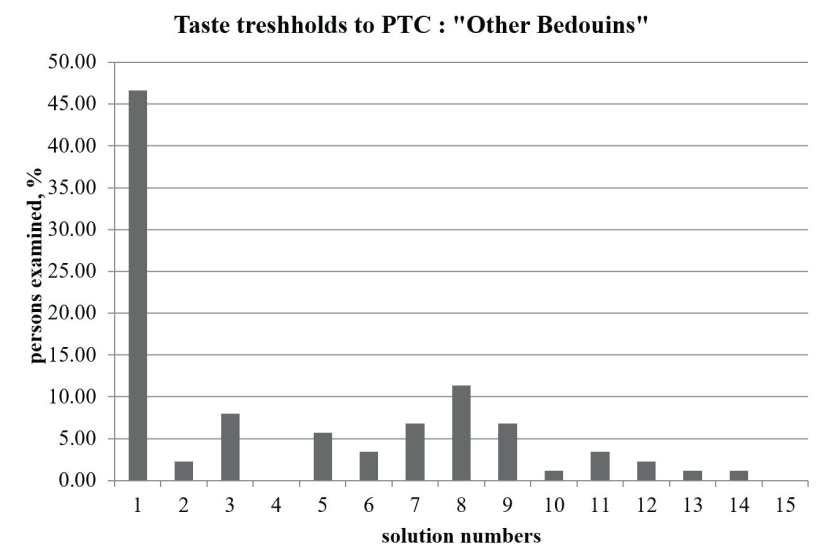

Fig. 4. Taste thresholds for PTC in "other Bedouin" tribes.

TABLE 1

SENSITIVITY DATA TO PTC IN BEDOUINS

\begin{tabular}{lcccc}
\hline & \multicolumn{4}{c}{ Tribe and sample size } \\
\cline { 2 - 5 } & $\begin{array}{c}\text { Gebeliya } \\
\mathrm{N}=71\end{array}$ & $\begin{array}{c}\text { Hamada } \\
\mathrm{N}=61\end{array}$ & $\begin{array}{c}\text { Muzeina } \\
\mathrm{N}=97\end{array}$ & $\begin{array}{c}\text { Other } \\
\text { Bedouins } \\
\mathrm{N}=88\end{array}$ \\
\hline Non-tasters, \% & 19.72 & 50.82 & 48.45 & 56.82 \\
Tasters, \% & 80.28 & 49.18 & 51.55 & 43.18 \\
t allele frequency & 0.4441 & 0.7129 & 0.6961 & 0.7538 \\
T allele frequency & 0.5559 & 0.2871 & 0.3039 & 0.2462 \\
\hline
\end{tabular}

An analysis of the frequencies of the $t$ allele encoding the inability to sense the taste of PTC exhibited significant pairwise differences $(p<0.01)$ between the Gebelia and the Muzeina, Hamada, and "other Bedouin tribes". Pairwise comparisons between the last samples did not reveal a statistically significant difference in the frequencies of the $t$ allele (Table 3 ). 
TABLE 2

PAIRWISE COMPARISON OF THE THRESHOLD SENSITIVITY INDICATORS TO PTC IN BEDOUIN TRIBES

\begin{tabular}{lccc}
\hline Compared tribes & $\chi^{2}$ test & DF. & p-value \\
\hline Gebelia-Hamada & 29.24 & 14 & 0.0097 \\
Gebelia -Muzeina & 32.41 & & 0.0035 \\
Gebelia - Other Bedouins & 30.49 & & 0.0065 \\
Hamada - Muzeina & 9.02 & & 0.8297 \\
Hamada - Other Bedouins & 22.27 & & 0.0732 \\
Muzeina- Other Bedouins & 25.07 & & 0.0339 \\
\hline DF - degree of freedom & & &
\end{tabular}

TABLE 3

PAIRWISE COMPARISON OF THE t ALLELE FREQUENCY IN BEDOUIN TRIBES

\begin{tabular}{lccc}
\hline Compared tribes & $\chi^{2}$ test & DF & p-value \\
\hline Gebelia-Hamada & 8.642 & 1 & 0.004 \\
Gebelia-Muzeina & 10.662 & 0.002 \\
Gebelia - Other Bedouins & 14.886 & $<0.001$ \\
Hamada-Muzeina & 0.003 & & $\begin{array}{c}\text { No significant } \\
\text { differences }\end{array}$ \\
Hamada - Other Bedouins & 0.510 & & $\begin{array}{c}\text { No significant } \\
\text { differences }\end{array}$ \\
Muzeina - Other Bedouins & 0.630 & & $\begin{array}{c}\text { No significant } \\
\text { differences }\end{array}$ \\
\cline { 1 - 1 } & & &
\end{tabular}

DF - degree of freedom

\section{Discussion}

The frequency of the tasters versus the non-tasters was statistically significantly higher only in the Gebelia tribe. In the Hamada, Muzeina, and "other Bedouin tribes", the number of non-tasters was almost equal to the number of tasters. Contributing to the formation of the Gebelia tribe gene pool was due to the partial crossbreeding of Bedouins with their Sudanese slaves ${ }^{19}$. The BlackAfrican admixture appears in the morphological features of Bedouins belonging to the Gebelia tribe. Authors in several studies have suggested an extremely low prevalence of PTC non-tasters amongst the indigenous BlackAfrican population ${ }^{3,23,24,25}$. It can, therefore, be assumed that the relatively low frequency of the $t$ allele, equivalent to 0.4441 , as well as the correspondingly low percentage of non-tasters amongst Gebelia males, is the result of a Black-African admixture, or convergent similarity (as described for various African populations ${ }^{26}$ ). The other three Bedouin tribes were characterized by significantly higher values of the frequencies of the $t$ allele which controls the insensitivity to the bitterness of PTC.

We illustrate (Figure 5) that the prevalence of nontasters in the Hamada, Muzeina, and the "other Bedouin tribes" demonstrated the highest rates between
TABLE 4

PAIRWISE COMPARISON OF MALE TASTERS AND NON-TASTERS' PREVALENCE IN BEDOUIN, JEWISH, ARAB, AND BLACK AFRICAN SAMPLES

\begin{tabular}{|c|c|c|}
\hline Compared tribes & $\chi^{2}$ test & p-value \\
\hline Gebelia - Middle Eastern Jews & 5.67 & 0.0200 \\
\hline Muzeina- Middle Eastern Jews & 2.22 & $\begin{array}{l}\text { No significant } \\
\text { difference }\end{array}$ \\
\hline Hamada - Middle Eastern Jews & 1.09 & $\begin{array}{l}\text { No significant } \\
\text { difference }\end{array}$ \\
\hline $\begin{array}{l}\text { Other Bedouins - Middle Eastern } \\
\text { Jews }\end{array}$ & 0.13 & $\begin{array}{l}\text { No significant } \\
\text { difference }\end{array}$ \\
\hline Gebelia - Egyptians & 0.10 & $\begin{array}{l}\text { No significant } \\
\text { difference }\end{array}$ \\
\hline Muzeina - Egyptians & 18.39 & $<0.0001$ \\
\hline Hamada - Egyptians & 21.99 & $<0.0001$ \\
\hline Other Bedouins - Egyptians & 18.39 & $<0.0001$ \\
\hline Gebelia - mixed Sudanese & 0.44 & $\begin{array}{l}\text { No significant } \\
\text { difference }\end{array}$ \\
\hline Muzeina - mixed Sudanese & 16.02 & 0.0001 \\
\hline Hamada-mixed Sudanese & 21.99 & $<0.0001$ \\
\hline Other Bedouins - Sudanese & 9.41 & 0.0020 \\
\hline \multicolumn{3}{|c|}{ Tribes comparison (by the exact Fisher test) } \\
\hline Gebelia - Sudanese & & 0.0004 \\
\hline Muzeina - Sudanese & & $<0.0001$ \\
\hline Hamada - Sudanese & & $<0.0001$ \\
\hline Other Bedouins- Sudanese & & $<0.0001$ \\
\hline
\end{tabular}

Arab, Jewish and African populations (according to the data obtained by the dilution method). The Gebelia tribe's data were nearly comparable to the values of several Arab samples, yet, differed from the Sudanese sample. The analysis included the prevalence of non-tasters for Jews in the Middle East, Egyptians, and Sudanese (Table 4). Comparisons of the population prevalence of non-tasters in Bedouin, Arab, Jewish, and sub-Saharan (Black-African) populations, revealed some convergence in prevalence between the Gebelia Bedouins and other Middle Eastern and North African samples. Significant differences were found only within the Middle Eastern Jewish group, (the frequency of the $t$ allele varied from 0.4087 to 0.5128 for immigrant Jews from Eastern Europe $\left.^{21}\right)$. The other Bedouin tribes did not differ from the Middle Eastern Jewish samples in terms of the prevalence of PTC non-tasters.

The prevalence of non-tasters in the Gebelia tribe was almost similar to the prevalence in the Egyptian population, however, other Bedouin tribes showed no such similarity. The results of comparing non-tasters in the Bedouin tribes and a mixed group of Sudanese appeared very similar. Exact Fisher's test demonstrated significant differences between the North Sudanese sample and each of the Bedouin tribes. 


\section{PTC sensitivity: non-tasters among some human populations, $\%$}

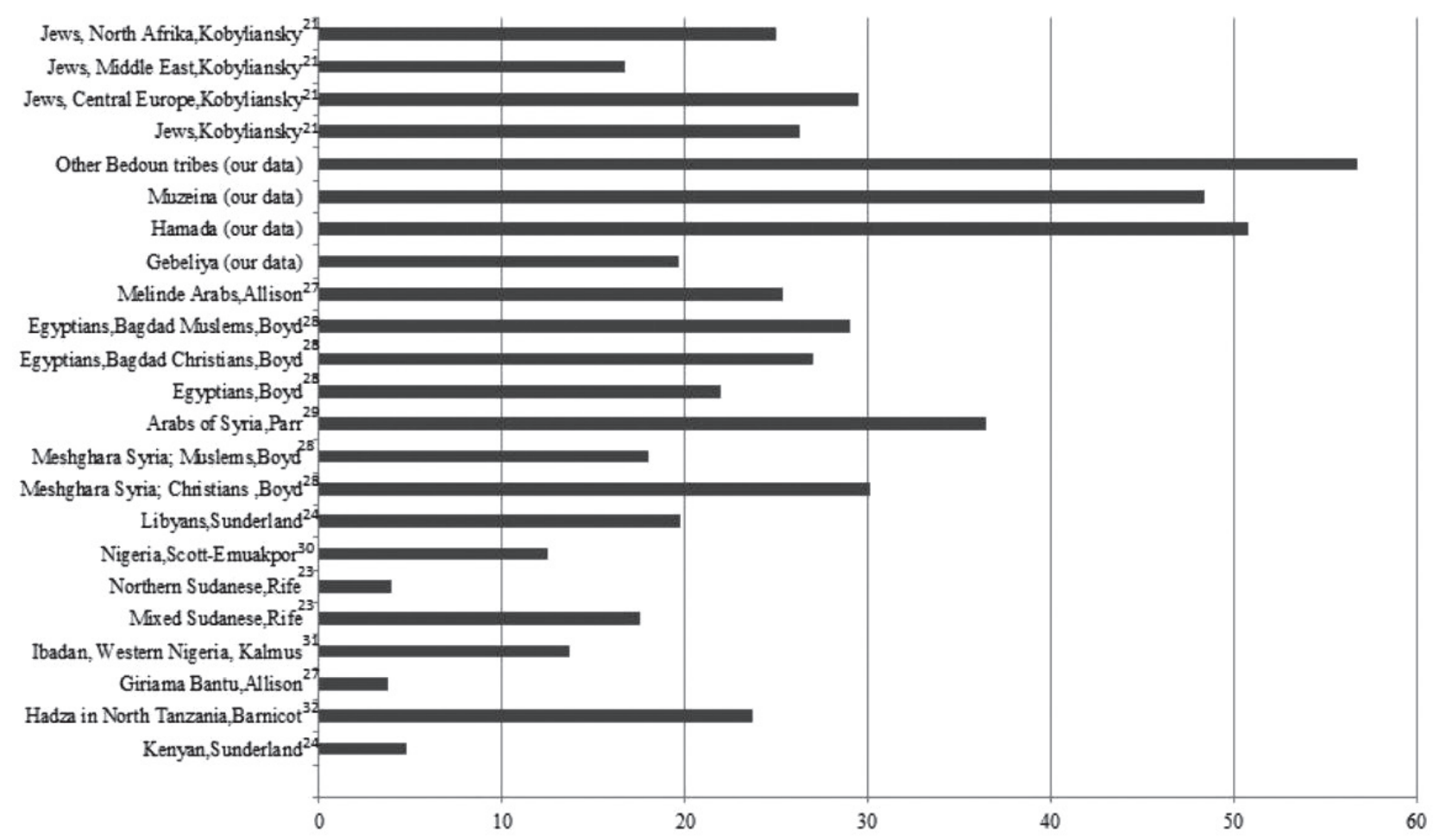

Fig. 5. Taste sensitivity to PTC amongst several human populations: non-tasters, \% (Data on Jewish samples taken from Kobyliansky et al. ${ }^{21}$; prevalences for all other non-Bedouin groups are given according to Guo and Reed $\left.{ }^{18}\right)$.

\section{Conclusions}

Our results demonstrated the presence of significant differences in chemosensitivity to PTC in the Bedouin samples. A high frequency of the $t$ allele was recorded in three Bedouin tribes: the Hamada, Muzeina, and "other Bedouin tribes", and a relatively low level of frequency in the Gebelia tribe. The prevalence of non-tasters amongst Arab groups was analogous to the Gebelia tribe. Three other Bedouin tribes showed a very high prevalence of non-tasters. The revealed intertribal differences can be explained by the genetic drift effect in isolated populations; however, endogamy may also be the reason for the

\section{R E F E R E N C E S}

1. RYCHKOVYG, BORODINA RG, Genetika, 9 (1973) 139. - 2. BEHRENS M, MEYERHOF W. Results Probl Cell Differ 52 (2010) 87. doi: 10.1007/978-3-642-14426-4_8. - 3. BARNICOT NA, Ann of Eugenics London, 15 (1950) 248. - 4.CAMPBELL MC, RANCIARO A, FROMENT A, HIRBO J, OMAR S, BODO JM, NYAMBO T, LEMA G, ZINSHTEYN D, DRAYNA D, BRESLIN PAS, TISHKOFF SA, Mol Biol Evol. 29 (2012) 1141. doi: 10.1093/molbev/msr293 - 5. RISSO D, BEHRENS M, SAINZ E, MEYERHOF W, DRAYNA D, Mol Biol Evol 34 (2017) 1587. doi: 10.1093/ molbev/msx097. - 6.RISSO DS, MEZZAVILLA M, PAGANI L, ROBINO A, MORINI G,TOFANELLI S, CARRAI M, CAMPA D, BARALE R, CARADONNA F, GASPARINI P, LUISELLI D, WOODING S, DRAYNA D, Sci Rep. 6 (2016) 25506. doi: 10.1038/srep25506. - 7. DOTY RL, increased levels of the $t$ allele frequency. Moreover, such low values of the $t$ allele in the Gebelia tribe may be the result of a partial crossbreeding of the Bedouins with their Sudanese slaves or simply the result of convergent processes.

\section{Acknowledgment}

The research was carried out within the state assignment of the Research Institute and Museum of Anthropology (Lomonosov Moscow State University): project № AAAA-A19-119013090163-2.

TOURBIER IA, PHAM DL, CUZZOCREO JL, UDUPA JK, KARACA LI B, BEALS E, FABIUS L, LEON-SARMIENTO FE, MOONIS G, KIM T, MIHAMA T, GECKLE RJ, YOUSEM DM, J Neurol. 263 (2016) 677. doi: 10.1007/s00415-016-8030-6. - 8. MENNELLA JA, PEPINO MY, DUKE FF, REED DR. Chem Senses. 36 (2011) 161. doi: 10.1093/chemse/ bjq106. - 9. TEPPER BJ, MELIS M, KOELLIKER Y, GASPARINI P, AHIJEVYCH KL, BARBAROSSA I, Nutrients. 9 (2017) 1275. doi: 10.3390/nu9121275. — 10. RAMOS-LOPEZ O, ROMAN S, MARTINEZ-LOPEZ E, GONZALEZ-ALDACO K, OJEDA GRANADOS C, SEPULVEDA-VILLEGAS M, PANDURO A, Ann Hepatol 14(5) (2015) 729. doi: 10.1016/S1665-2681(19)30768-9. - 11. SHIZUKUDA S, MARCHINI JS, ADELL A, SANTOS MA, BRANDAO CFC, LIMA CMM, CUNHA 
SFC, ITIKAWA EN, SILVAH JH, Nutrire, 43:4 (2018). doi: 10.1186/ s41110-018-0069-y. — 12. LEBEDEVA YG, SLAVOLYUBOVA IA. Anthropological aspects of studying the taste sensitivity to phenylthiocarbamide in the Chuvashes, In: DERYABIN VE (Eds.) Anthropological monitoring of the population of Chuvashia (Cheboksary, CHGIGN, 2009). — 13. WOODING S, KIM UK, BAMSHAD JM, LARSEN J, JORDE LB, DRAYNA D, Am J Hum Genet. 74:4 ( 2004) 637. doi: 10.1086/383092.— 14. KIM UK, DRAYNA D. Clin Genet 67 (2005) 275. doi: 10.1111/j.1399-0004.2004.00361.x. - 15. GENICK UK, KUTALIK Z, LEDDA M, SOUZA DESTITO MC, SOUZA M., CIRILLO CA, GODINOT N, MARTIN N, MORYA E, SAMESHIMA K, BERGMANN S, LE COUTRE J. PLoS ONE, 6:11 (2011) e27745. doi: 10.1371/journal. pone.0027745. - 16. FISCHER ME, CRUICKSHANKS KJ, PANKOW JS, PANKRATZ N, SCHUBERT CR, HUANG GH, KLEIN BE, KLEIN R, PINTO A, J Nutrigenet Nutrigenomics, 7:3 (2014) 143. doi:10.1159/000371552. - 17. ROBINO A, MEZZAVILLA M, PIRASTU N, DOGNINI M, TEPPER BJ, GASPARINI P, PLoS ONE 9 (2014) e91716. doi: 10.1371/journal.pone.0091716 - 18. GUO S-W, REED DR,
Annals of Hum Biol, $28: 2$ (2001) 111. doi: 10.1080/03014460151056310. - 19. CHUMAKOVA AM, KOBYLIANSKY ED, Bull of Moscow University Series 23: Anthropology, 3 (2012) 72.-20. HARRIS H, KALMUS H, Ann Eugen (London), 15 (1949) 32. - 21. KOBYLIANSKY E, MICLE S, ARENSBURG B, GOLDSCHMIDT-NATHAN M, NATHAN H, Coll Antropol, 5 (1981) 81. - 22. MIATCHINA OV, SKYBA OS, VELYTCHKO LG, Bull of the Ukrainian Medical Dental Academy, 10 (2010) 109. — 23. RIFE DC, Am J Phys Anthropol, 11 (1953) 189. — 24. SUNDERLAND E, ROSA PJ, Hum Biol, 47 (1975) 473. — 25. JENKINS T, Hum Biol, 37 (1965) 371. - 26. CAMPBELL MC, TISHKOFF SA, Curr Biol 20 (2010) R166. doi: 10.1016/j.cub.2009.11.050. - 27. ALLISON AC, Man, 204 (1951) 119. - 28. BOYD WC, Genetics and the races of man. An introduction to modern physical anthropology (Little, Brown and Company, Boston,1950). - 29. PARR LWJ, Heredity, 25 (1934) 187. 30. SCOTT-EMUAKPOR AB, UVIOVO JE, WARREN ST, Hum Hered, 25 (1975) 360. doi: 10.1159/000152747. — 31. KALMUS H, Hum Biology, 39 (1967) 32.- 32. BARNICOT N, WOODBURN J, Ann Hum Biol, 2 (1975) 61. doi: 10.1080/03014467500000571.

\section{E. Kobyliansky}

Department of Anatomy and Anthropology, Sackler Faculty of Medicine, Tel-Aviv University, Ramat-Aviv, Israel 69978. e-mail: anatom14@post.tau.ac.il

\section{OSJETLJIVOST OKUSA NA FENILTIOKARBAMID (PTC) MEĐU BEDUINSKIM PLEMENIMA NA SINAJSKOM POLUOTOKU}

\section{S A Ž E T A K}

Cilj ovog rada bio je istražiti osjetljivost okusa na feniltiokarbamid (PTC) među beduinskim plemenima i usporediti Beduine s arapskom i židovskom populacijom. Podaci su dobiveni klasičnom metodom kod 317 zdravih muških Beduina, starih 16-70 godina koji pripadaju različitim plemenima. Otkrili smo značajne razlike u kemoosjetljivosti na PTC u beduinskim zajednicama. Visoka učestalost $t$ alela zabilježena je u beduinskim plemenima Hamada, Muzeina i "drugim Beduinima", a relativno niska razina frekvencije $t$ alela nađena je u plemenu Gebelia. Učestalosti neosjetljivosti među arapskim skupinama bile su slične vrijednostima utvrđenim u plemenu Gebelia. Tri druga beduinska plemena pokazala su vrlo visoku učestalost neosjetljivosti. Otkrivene međuplemenske razlike mogu se objasniti genetskim pomakom u izoliranim populacijama, ili utjecajem endogamije. 